\title{
The Pathology of Hereditary Breast Cancer
}

\author{
Emiliano Honrado', Javier Benítez', José Palacios² \\ IHuman Genetics Department; ${ }^{2}$ Group of Breast and Gynecological Cancer, Centro Nacional de Investigaciones Oncológicas (CNIO), Madrid, Spain
}

Key words: $B R C A 1, B R C A 2$, non-BRCA1/2, histopathology

Corresponding author: José Palacios, MD, Group of Breast and Gynecological Cancer. Molecular Pathology Programme. Centro Nacional Investigaciones Oncológicas (CNIO). Melchor Fernández Almagro No 3, 28029 Madrid, Spain. Phone+34912246952,fax+34912246923,e-mail: jpalacios@cnio.es

Submitted: 12 July 2004

Accepted: 30 July 2004

\begin{abstract}
Several studies have demonstrated that familial breast cancers associated with BRCA1 or BRCA2 germline mutations differ in their morphological and immunohistochemical characteristics. Cancers associated with BRCA1 are poorly differentiated infiltrating ductal carcinomas (IDCs) with higher mitotic counts and pleomorphism and less tubule formation than sporadic tumours. In addition, more cases with the morphological features of typical or atypical medullary carcinoma are seen in these patients. Breast carcinomas from BRCA2 mutation carriers tend to be of higher grade than sporadic age-matched controls. Regarding immunophenotypic features. BRCA 7 tumours have been found to be more frequently oestrogen receptor- (ER) and progesterone receptor(PR) negative, and p53-positive than age-matched controls, whereas these differences are not usually found in BRCA2-associated tumours. A higher frequency and unusual location of p53 mutations have been described in BRCA $1 / 2$ carcinomas. Furthermore, BRCA 1 - and BRCA2-associated breast carcinomas show a low frequency of HER-2 expression. Recent studies have shown that most BRCA1 carcinomas belong to the basal cell phenotype, a subtype of high grade, highly proliferating ER/HER2-negative breast carcinoma characterized by the expression of basal or myoepithelial markers, such as basal keratins, P-cadherin, EGFR, etc. This phenotype occurs with a higher incidence in BRCA1 tumours than in sporadic carcinomas and is rarely found in BRCA2 carcinomas. Hereditary carcinomas not attributable to BRCA1/2 mutations have phenotypic similarities with BRCA2 tumours, but tend to be of lesser grade and lower proliferation index. The pathological features of hereditary breast cancer can drive specific treatment and influence the process of mutation screening.
\end{abstract}

\section{Introduction}

It is currently estimated that $5-10 \%$ of all breast cancers are hereditary and attributable to mutations in several highly penetrant susceptibility genes, of which only two have been identified: BRCA1 (OMIM 113705 ) [1] and BRCA2 (OMIM 600185) [2]. Earlier estimates suggested that BRCA1 and BRCA2 mutations were responsible for $75 \%$ of site-specific breast cancer families and the majority of breast and ovarian cancer families [3, 4]. Recent data shows however that these percentages may have been overestimated and that the proportion of families classified due to mutations in BRCA1 or BRCA2 is much lower and strongly depends on the population analyzed [5] and the specific characteristics of the selected families [6, 7]. In fact, the percentage of high risk families associated with mutations in these genes is very similar (around $25 \%$ in all series, including the one we have found in Spain $[8,9]$. 
Table 1. Morphological and immunohistochemical profiles associated with hereditary breast cancer tumours

\begin{tabular}{lcccccccc}
\hline & GRADE & RE & RP & BCL2 & P53 & Ki-67 & Cyclin D1 & CK5/6 \\
\hline BRCA1 & 3 & - & - & - & ++ & ++ & - \\
\hline BRCA2 & $2 / 3$ & + & + & + & + & + & + \\
\hline non-BRCA1/2 & $1 / 2$ & + & + & + & - & - & - \\
\hline
\end{tabular}

Genetic testing for BRCA1 and BRCA2 is expensive and time-consuming due to the large size of both genes, the absence of hot spots for mutations throughout their entire coding regions, and the low percentage of mutated cases. It is therefore important to find clinical or pathological factors that could suggest or exclude the presence of BRCA1 or BRCA2 mutations in a given patient.

The histopathology of BRCA-associated cancer has been studied by different groups; however the larger series are those reported by the Breast Cancer Linkage Consortium (BCLC) [10-12]. These studies have demonstrated that cancer arising in carriers of mutations in either the BRCA1 or BRCA2 genes differs morphologically from sporadic breast cancers from age-matched controls [1 1-14]. In addition, numerous immunohistochemical studies have tried to better characterize the differences between hereditary and sporadic tumours [10, 15-18]. More recently, some reports have also described the pathology of hereditary breast cancer not attributable to BRCA1 or BRCA2 germline mutations. The purpose of this review is to present the histopathological characteristic of different genotypes of hereditary breast cancer. Special attention will be given to those characteristics that possibly impact on genetic testing, prognosis and treatment.

\section{Histopathology of BRCA1 and BRCA2 breast cancer}

In order to better understand the specific characteristics of hereditary breast cancer, the histopathological and immunohistochemical variables usually evaluated in sporadic breast cancer are also presented, since invasive breast carcinoma is a heterogeneous group of malignant epithelial tumours with a wide range of morphological phenotypes and specific histopathological types.

\section{Histological type}

Invasive ductal carcinoma (IDC) not otherwise specified (NOS) is the most common histological type among sporadic breast cancer, comprising $70-80 \%$ of all cases. The most frequent special histological types are invasive lobular carcinoma (5-15\%), tubular carcinoma $(2 \%)$, invasive cribriform carcinoma (0.8-3.5\%), medullary carcinoma (1-7\%), mucin producing carcinoma (2\%), neuroendocrine tumours $(2-5 \%)$, invasive micropapillar carcinoma (2\%). Differences between series are related with the specific population studied or, more probably, with stringency in the application of diagnostic criteria.

Medullary carcinoma is a particular type of carcinoma characterized by the presence of solid sheets of large and pleomorphic cells with indistinct cell borders that lead to a syncytial appearance [19]. They are high-grade tumours with numerous mitosis, and sparse necrosis $(<25 \%)$. The border of the tumour is well defined with a pushing edge. The stroma is a dense lymphocytic infiltrate. Despite being a high-grade tumour, it has been associated with a relatively favourable prognosis [19-21]. Atypical medullary carcinoma is diagnosed when more than $25 \%$ of tumour is not classical medullary or the lymphoid infiltration is moderate or the circumscription is not complete.

IDC NOS is the most common histological type in all forms of hereditary breast cancer and it seems to be significantly more frequent in BRCA1 and BRCA2 mutation carriers than in non-carriers [22]. In addition, BRCA7 mutation carriers have a higher incidence of medullary carcinoma (13\%) than BRCA2 mutation carriers (3\%) and non-carriers (2\%) [12]. When only IDC cases are compared, after excluding medullary carcinomas, BRCA 1 tumours have more frequently a prominent lymphocytic infiltrate and pushing margins [1 1], some of the features that define the medullary histotype.

Regarding BRCA2 carcinomas, Marcus et al have reported a higher incidence of BRCA2 tumours belonging to a "tubular lobular group", including invasive lobular, tubular and cribriform carcinomas [23, 24]. Armes et al found that BRCA2 mutation carriers showed an excess of pleomorphic lobular and intraductal carcinomas [13]. However, other series have not found any statistically significant difference in the histological type of BRCA2 with respect to controls $[11,12,25]$.

\section{Histological grade}

Breast carcinomas are routinely graded based on an assessment of tubule formation, nuclear pleomorphism 
and mitotic counts. This method of tumour graduation consists of scoring 1-3 for each factor. The grade is obtained by adding the three previous parameters and classifying the tumour as grade 1 (well differentiated or low-grade), grade 2 (moderately differentiated or intermediate-grade) and grade 3 (poorly differentiated or high-grade). This grading system has prognostic implications and the utility has been convincingly proved $[26,27]$.

BRCAl tumours are more frequently high-grade (grade 3) tumours because they show less tubule formation, higher pleomorphism and a higher number of mitosis than sporadic age-matched breast cancer controls. Thus, the reported incidence of grade 3 tumours in BRCA1 mutation carriers ranged from $66 \%$ to $84 \%$ in different studies $[12,28,29]$ while the proportion of grade 3 tumours in sporadic age-matched breast cancer controls was between $30 \%$ and $40 \%[12,28,29]$.

BRCA2 tumours tend to be of higher grade than sporadic controls, although this association is less strong than for BRCA1 cases. Most BRCA2 tumours are grade $2 / 3$, and show less tubule formation but similar cellular pleomorphism and mitotic count than sporadic cases [12]. Furthermore this difference in tubule formation, Agnarsson et al [25] have reported more nuclear pleomorphism and higher mitotic rates in BRCA2 tumours than in sporadic tumours.

\section{Hormone receptors and associated markers}

Sporadic breast cancer tumours express a number of immunohistochemical markers that provide prognostic and predictive information about these tumours. In this sense, approximately $70 \%$ of breast carcinomas express the oestrogen receptor (ER) protein and $50 \%$ are progesterone receptor- (PR) positive. ER-positive tumours are more frequently well or moderately differentiated, p53- and HER2-negative and have a lower proliferation rate and better overall survival, but do not have a lower metastatic potential. ER-positive and PR-positive tumours respond to anti-oestrogen treatment in approximately $75 \%$ of the cases. The response is $34 \%$ when the tumour is ER-positive and PR-negative, and $45 \%$ in the case of ER-negative and PR-positive tumours. Only a small proportion of ER-negative and PR-negative $(<10 \%)$ respond to anti-oestrogens, perhaps reflecting false negative ER measurement [30].

Many authors have emphasized the high frequency of ER-negativity in BRCA 1 tumours, $[10,18,28,29$, $31-34]$. Between $73 \%$ and $90 \%[28,29,31]$ of BRCA1 carcinomas have been reported to be ER-negative in different series. Although it has been suggested that this relationship might be explained by the higher grade of tumours and younger age of patients, BRCA 1 tumours are more likely ER-negative than sporadic ones, when tumours from patients at the same age are compared. In addition, the likelihood of ER-negativity is 4.8 times higher in BRCA1 grade 3 tumours when they are compared with grade 3 sporadic cases [18]. In this sense, for example, Lakhani et al [10] reported that $90 \%$ of BRCA1-related breast cancers were ER-negative compared with $35 \%$ in controls.

PR expression in BRCAl tumours is also lower than in sporadic tumours. In the study of Lakhani et al [10] $79 \%$ of BRCA1 tumours were PR-negative compared with $41 \%$ in sporadic tumours. The same proportion has been observed in other publications $[28,29,31]$.

In contrast to BRCAl tumours, those arising in BRCA2 mutation carriers do not differ from controls with regard to ER and PR expression. Thus, ER expression has been reported in around $65 \%$ of BRCA2 tumours $[10,31,32]$. Between $40 \%$ and $60 \%$ of BRCA2 carcinomas expressed PR [10, 31, 32].

Taking into account the differences in hormone receptor status between BRCA1 and BRCA2 tumours, it is not surprising that the expression of some markers is consistently associated with hormone receptors in breast cancer, such as Bcl-2 and cyclin Dl, and differ between both genotypes. $\mathrm{Bcl}-2$ is a protein that inhibits programmed cell death (apoptosis). This protein is detected in $50-90 \%$ of IDC of the breast $[35,36]$. Bcl2 expression is associated with favourable clinicopathological features [37]. Thus, it is more frequently present in well-differentiated ER-positive breast carcinomas. Bcl-2-positive p53-negative tumours have a better response to hormonal therapy than bcl2-negative p53-positive ones [35]. Bcl-2 has a low rate of expression in BRCA1-associated tumours (31\%) with respect to sporadic carcinomas [28, 38], but there are no statistically significant differences between BRCA2 and sporadic tumours [38].

Cyclin D1 plays an important role in cell cycle progression during $\mathrm{G} 1$ phase. Cyclin D1 is considered a potential oncogene and is amplified in about 15\% of IDCs [39]. Cyclin D1 is known to be upregulated by oestrogen and progesterone and to be downregulated by anti-oestrogens [40]. The cyclin D1 protein is detected in 50\% of cases [41] and its expression is associated with low histological grade, ER positivity and good prognosis. Several series have detected lower cyclin D1 expression levels in BRCA1 (5\% and 33\%) than in sporadic tumours [31, 33, 42]. Cyclin D1 expression in BRCA2 tumours has been found at an intermediate level between BRCAl and sporadic tumours. Osin et al [33] reported that $27 \%$ of BRCA2 tumours expressed cyclin D1 compared with $5 \%$ in 
BRCA 1 tumours, and 35\% in sporadic tumours. In the same way, Armes et al [31] has shown cyclin D1 positivity in $55 \%$ of BRCA2, 33\% of BRCA1 and $100 \%$ of sporadic tumours.

\section{p53 expression and gene mutations}

Around $15 \%$ to $30 \%$ of sporadic breast carcinomas have mutations in the tumour suppressor gene $p 53$. Most of them are missense mutations that result in the accumulation of stable p53 protein that can be visualized by immunohistochemistry. However, 20\% of the mutations do not yield a stable protein and it is not detected by immunostaining. For this reason, a stronger association between clinicopathological variables and p53 mutations, detected by DNA sequencing has been shown rather than with p53 immunohistochemistry detection in breast cancer.

Several studies have demonstrated a high incidence of p53 immunostaining in BRCA 1 when compared to sporadic cases. p53 over-expression has been detected in $45 \%$ to $77 \%$ of BRCA 1 -associated tumours [10, 28, $29,43,44]$. The results in BRCA2 tumours are inconclusive [10]. Some studies have found p53 overexpression in around $50 \%$ of BRCA2 carcinomas, whereas in other series the percentage was lower than $20 \%$ [28].

The importance of p53 inactivation in BRCA-associated tumours is also supported by genetic studies demonstrating a higher frequency and unusual location of $p 53$ mutations in this group when compared with sporadic cases [43-45]. In a review of reported cases by Chappuis et al [22] around $40 \%$ of BRCAl and 30\% of BRCA2 carcinomas had p53 mutations whereas it was found in only about $20 \%$ of sporadic controls. When comparing the spectrum of p53 mutations in BRCA1/2 patients with those reported in the IARC p53 mutation database, Greenblatt et al [46] found that they differed significantly both in distribution and in base changes. Mutations at A:T bp were common in BRCA1/2 associated tumours. Changes were frequent at p53 codons that are not mutation hotspots and were located at the opposite side of the p53 DNA-binding site.

\section{HER2 expression and gene amplification}

HER2 is the human epidermal growth factor receptor-2 that encodes a transmembrane glycoprotein with intrinsic tyrosine kinase activity. HER2 gene is located in chromosome 17q12 and has been associated with poor outcome and poor response to anti-oestrogens, but a better response to anthracyclines. Over-expression of HER-2 is identified in $10 \%$ to $34 \%$ of primary breast tumours $[47,48]$ and is attributable to gene amplification in approximately $90 \%$ of cases $[49,50]$. The humanized anti-HER-2 monoclonal antibody, Herceptin, has been shown to be effective in $20 \%$ of patients with HER-2 amplification.

Data regarding HER2 expression in BRCA-associated tumours vary among series, probably indicating technical issues. For example, Armes et al [31] have shown no differences in strong expression of HER-2 between BRCA2 and sporadic breast tumours, $44 \%$ and $45 \%$ respectively, but they did not find HER-2 expression in any BRCA 1 tumours. However, subsequent studies have observed HER2 over-expression in up to $3 \%$ in both BRCA1 and BRCA2 tumours $[10,28,51]$. With regard to the HER-2 amplification, only two studies have analyzed gene status by FISH in hereditary BRCA 1 -associated carcinomas [28, 52], and only one in BRCA2-associated carcinomas. According to immunohistochemistry data, high level of HER-2 amplification (>2.4 copies) has not been reported in BRCA1 and BRCA2 tumours.

\section{BRCAl carcinomas and the basal cell phenotype}

Sorlie et al $[53,54]$ using cDNA microarrays classified breast tumours into clinically relevant subgroups. They defined different subtypes of breast tumours, including two non-overlapping groups of ER-negative carcinomas: the basal like and the ERBB2 over-expressing groups. The basal cell phenotype is characterized by the expression of markers that are usually expressed by the basal or myoepithelial cells of the normal breast. The group of myoepithelial/basal markers include the basal epithelial keratins (CK) 5/6, 14, and 17, muscle-specific actin, P-cadherin, S100, CD10, caldesmon, calponin, EGFR etc. [55-57]. The existence of a group of breast carcinomas with a basal cell phenotype has been confirmed by other groups using DNA microarray and immunohistochemical approaches [58-60]. Some of these studies have also indicated the poor prognosis of this group of neoplasias $[17,55,56]$.

Recently Sorlie et al [53] reanalyzing cDNA microarray data from van't Veer et al [61], that included 18 BRCA1 and 2 BRCA2 carcinomas, observed that $80 \%$ of BRCA 1 carcinomas had a basal epithelial type gene expression profile. Subsequently, Foulkes et al and Palacios et al have found a high prevalence of tumours with a basal phenotype among BRCA1 mutation carriers. For example, Palacios et al [60] reported that CK 5/6 was expressed in 50\% of BRCA1 tumours but in less than $10 \%$ of BRCA2 cases and sporadic controls. In addition this phenotype is characterized by ER and HER2 negativity and the expression of specific cell cycle markers, such as over-expression of cyclin $E$ and down-regulation of p27. Interestingly, a high proportion 
(60\%) of BRCA1 carcinomas have been reported to over-express EGFR [10, 16, 57, 60, 62].

\section{Histopathology of familial non-BRCA1/2 tumours}

There are two studies that have defined the histological characteristics of these neoplasias [28, 63]. This group of tumours represents $67 \%$ of familial breast cancer when families with only female breast cancer and $4-5$ affected members are considered [6]. In the Spanish population, when considering families with at least three cases of female breast cancer and one of them $<50$ years, the percentage of cases nonattributable to BRCA1/2 mutation was $75 \%$ [8].

IDC is the most frequent histological type in familial non-BRCA1/2: $77 \%$ of the cases according to Lakhani et al [63] and 78\% in the series by Palacios et al [28]. An excess of lobular carcinomas was found in familial non-BRCAl/2 (15\%) when compared with BRCAl (3\%), BRCA2 (9\%) and sporadic cases (10\%). The difference was only significant with respect to BRCA1 tumours [63].

Breast cancers from familial non-BRCA1/2 patients were of lesser histological grade than BRCA1/2associated tumours $[28,63]$. Thus, grade 1 tumours accounted for $27 \%$ to $50 \%$ in total. In addition, non-BRCA1/2 tumours showed more tubule formation, a lower mitotic index and lesser pleomorphism than BRCA1/2-associated carcinomas [28, 63].

In the only immunohistochemical study in familial non-BRCA1/2 [28], these tumours were more frequently ER- $(75 \%)$, PR- $(67 \%)$, and BCL2-positive (55\%), but p53-negative (3.7\%); these figures clearly differed from BRCAl tumours, but no significant differences were found with respect to BRCA2 carcinomas. A low incidence of HER2 expression and amplification (4\%) was found in non-BRCA1/2 carcinomas [28].

\section{Pathology findings in prophylactic mastectomy specimens from BRCA1/2 mutation carriers}

The natural history of hereditary breast cancer from morphologically normal epithelium to invasive disease is not well understood. The incidence of in situ lesions associated with invasive carcinomas is poorly described in most publications. Overall, an in situ component is less common around IDC in BRCA1 mutation carriers than in controls [12]. In addition, the incidence of in situ lesions in the absence of an invasive component in familial breast cancer is not established.

The study of prophylactic mastectomy specimens from BRCA1/2 mutation carriers has been proposed as a means to better understand the different stages of breast cancer development in these patients. However, the lack of data available is not conclusive due to the low number of case studies and the difficulty in selecting appropriate controls which is confounded by difficulties in recognizing precursor lesions.

Hoogerbrugge et al have reported a study with 67 patients at high risk of breast cancer, 44 of them with BRCA mutation, who underwent unilateral or bilateral prophylactic mastectomy. One or more different types of high-risk precursor lesions were present in $57 \%$ of the women: $37 \%$ had atypical lobular hyperplasia (ALH), $39 \%$ atypical ductal hyperplasia (ADH), 25\% lobular carcinoma in situ (LCIS), and 15\% ductal carcinoma in situ (DCIS). A 4-mm invasive ductal carcinoma was found in one woman with ductal carcinoma in situ. Prior to mastectomy, palpation or mammography was performed and none of these lesions were detected. These high risk lesions were more frequent in the group of women aged 40 years and older (73\% vs. $43 \%$ ) and less frequent in BRCA mutation carriers (43\%) and women who had undergone bilateral oophorectomy before prophylactic mastectomy (20\%) [64].

In another study, Kauff et al [65] compared prophylactic mastectomy specimens from 24 women with BRCA mutations and 48 controls extracted from an autopsy registry, concluding that BRCA mutation carriers have a higher incidence of high risk lesions including DCIS, LCIS, ADH or ALH (46\%) compared to control cases (6\%).

Adem et al [66] compared prophylactic mastectomy from patients with a family history of breast cancer including $28 \mathrm{BRCAl} / 2$ mutation carriers, 117 women without BRCA1/2 mutation, 12 unclassified mutation variant carriers, and 283 sporadic control cases. They found similar prevalence of DCIS in all groups $53 \%, 60 \%$, $56 \%, 55 \%$, respectively. However, in BRCA1/2 mutation carriers, the prevalence of proliferative fibrocystic changes was lower (7\%) compared with $25 \%$ in sporadic cases. In contrast, the proportion of invasive carcinomas was higher in mutation and unclassified variant alteration carriers compared with the control group and the mutation negative group, suggesting a faster progression of precursor lesions in mutation carriers.

\section{Genetic testing and therapeutic implications}

Available data concerning morphological and immunohistochemical characteristics of hereditary breast cancer demonstrated major differences between genotypes. The most important differences were found between tumours in BRCAl carriers and all other categories. These histopathological features in conjunction with clinical data can be used to predict 
BRCA1 status and to a lesser extent BRCA2 and non-BRCA1/2 status and this could have implications for the process of mutation screening.

In this sense, it has been suggested that the immunohistochemical analysis of $E R$, together with age and histological grade, provides a new powerful predictor of BRCA7 mutation status. It has been estimated that the probability of a woman with familial breast cancer diagnosed before 35 years to be a BRCAl mutation carrier is $25 \%$ if the tumour is grade 3 and ER-negative but the probability is only $5 \%$ if the tumour is ER-positive [10]. Taken into account the high proportion of $\mathrm{BRCA} 1$ carcinomas that express basal markers (i.e. CK 5/6), it is likely that the addition of such markers in the pathological study will improve our ability to predict the BRCA1 genotype.

Alternatively, if we have a tumour which is high grade (grade 2-3), ER-, and PR-positive and CK5/6-negative in a family with more than six female breast cancers in the first and second generations, early-onset prostate cancer or male breast cancer, it is likely we are dealing with a BRCA2 tumour.

Finally, it is very rare to find a BRCA1 or BRCA2 mutation when we are confronted with a low grade tumour (grade 1) with high tubule formation, ER- and PR-positive and p53-negative and a very low proliferation index. The probability of being a non-BRCA1/2 tumour increases if there are between three and six female breast cancer cases in the family, without ovarian cancer or early onset prostate cancer. In such a situation, probably it would be sufficient to study only the more recurrent mutations in each population in order to reduce the possibility of leaving atypical positive cases without diagnosis.

From a therapeutic point of view, adjuvant hormone therapy is not indicated in most BRCA1 tumours, since they are ER- and PR-negative, but can be used in most BRCA2 and non-BRCA1/2 carcinomas. The use of hormone therapy as chemopreventive drugs in BRCA1 patients is debatable [18,32, 67-70]. Taking into account the low incidence of HER2 amplification/overexpression in most hereditary breast cancer, these tumours are not good candidates for treatment with Herceptin. However, the high incidence of EGFR recently reported in BRCA1 tumour [62] opens the possibility that these women can be treated with specific compounds, such as tyrosine kinase inhibitors or antiEGFR monoclonal antibodies.

\section{References}

1. Miki Y, Swensen J, Shattuck-Eidens D, Futreal PA, Harshman K Tavtigian S, Liu Q, Cochran C, Bennett LM, Ding W, Bell R, Rosenthal J, Hussey C, Trant T, Mc Clure M, Frye C, Hattier T, Phelps R, Haugen-Strano A, Katcher H, Yakumo K, Gholami Z,
Saffer D, Stone S, Bayer S, Wray C, Bogden R, Dayananth P, Ward J, Tonin P, Narod S, Bristow PK, Norris FH, Helvering L, Morrison P, Rosteck P, Lai M, Barret JC, Lewis C, Neuhausen S, Cannon-Albrigh LA, Goldgar D, Wiseman R, Kamb A and Skolnick $\mathrm{MH}$. A strong candidate for the breast and ovarian cancer susceptibility gene BRCA1. Science 1994; 266: 66-71.

2. Wooster R, Bignell G, Lancaster J, Swift S, Seal S, Mangion J, Collins N, Gregory S, Gumbs C and Micklem G. Identification of the breast cancer susceptibility gene BRCA2. Nature 1995; 378: 789-792.

3. Easton DF, Bishop DT, Ford D and Crockford GP. Genetic linkage analysis in familial breast and ovarian cancer: results from 214 families. The Breast Cancer Linkage Consortium. Am J Hum Genet 1993; 52: 678-701.

4. Stratton MR, Ford D, Neuhasen S, Seal S, Wooster R, Friedman LS, King MC, Egilsson V, Devilee P, McManus R, Daly PA, Smyth E, Ponder BA, Peto J, Cannon-Albright LA, Easton DF and Goldgar DE. Familial male breast cancer is not linked to the BRCA1 locus on chromosome 17q. Nat Genet 1994; 7: 103-107.

5. Szabo $\mathrm{Cl}$ and King MC. Population genetics of BRCA1 and BRCA2. Am J Hum Genet 1997; 60: 1013-1020.

6. Ford D, Easton DF, Stratton M, Narod S, Goldgar D, Devilee P, Bishop DT, Weber B, Lenoir G, Chang-Claude J, Sobol H, Teare MD, Struewing J, Arason A, Scherneck S, Peto J, Rebbeck TR, Tonin P, Neuhausen S, Barkardottir R, Eyfjord J, Lynch H, Ponder BA, Gayther SA, Birch JM , Lindblom A, Stoppa-Lyonnet D, Bignon Y, Borg A, Hamann U, Haites N, Scott RJ, Maugard CM, Vasen H, Seitz S, Cannon-Albright LA, Schofield A, ZeladaHedman M and the Breast Cancer Linkage Consortium. Genetic heterogeneity and penetrance analysis of the BRCA1 and BRCA2 genes in breast cancer families. Am J Hum Genet 1998; 62: 676-689

7. Shih HA, Couch FJ, Nathanson KL, Blackwood MA, Rebbeck TR, Armstrong KA, Calzone K, Stopfer J, Seal S, Stratton MR and Weber BL. BRCA1 and BRCA2 mutation frequency in women evaluated in a breast cancer risk evaluation clinic. J Clin Oncol 2002; 20: 994-999.

8. Osorio A, Barroso A, Martinez B, Cebrian A, San Roman JM, Lobo F, Robledo $M$ and Benitez J. Molecular analysis of the BRCA1 and BRCA2 genes in 32 breast and/or ovarian cancer Spanish families. Br J Cancer 2000; 82: 1266-1270.

9. de la Hoya M, Osorio A, Godino J, Sulleiro S, Tosar A, Perez-Segura P, Fernandez C, Rodriguez R, Diaz-Rubio E, Benitez J, Devilee P and Caldes T. Association between BRCA 1 and BRCA2 mutations and cancer phenotype in Spanish breast/ovarian cancer families: implications for genetic testing. Int J Cancer 2002; 97: 466-471.

10. Lakhani SR, Van De Vijver MJ, Jacquemier J, Anderson TJ, Osin PP, McGuffog L and Easton DF. The pathology of familial breast cancer: predictive value of immunohistochemical markers estrogen receptor, progesterone receptor, HER-2, and p53 in patients with mutations in BRCA1 and BRCA2. J Clin Oncol 2002; 20: 2310-2318.

11. Lakhani SR, Jacquemier J, Sloane JP, Gusterson BA, Anderson TJ, van de Vijver MJ, Farid LM, Venter D, Antoniou A, StorferIsser A, Smyth E, Steel CM, Haites N, Scott RJ, Goldgar D, Neuhausen S, Daly PA, Ormiston W, McManus R, Scherneck S, Ponder BA, Ford D, Peto J, Stoppa-Lyonnet D, Bignon YJ, Struewing JP, Spurr NK, Bishop DT, Kliin JG, Devilee P, Cornelisse CJ, Lasset C, Lenoir G, Barkardottir RB, Egilsson V, Hamann U, Chang-Claude J, Sobol H, Weber B, Stratton MR and Easton DF. Multifactorial analysis of differences between sporadic breast cancers and cancers involving BRCA1 and BRCA2 mutations. J Natl Cancer Inst 1998; 90: $1138-1145$. 
12. Lakhani SR, Easton DF, Stratton MR, and Consortium +BCL. Pathology of familial breast cancer: differences between breast cancers in carriers of BRCA1 or BRCA2 mutations and sporadic cases. Breast Cancer Linkage Consortium. Lancet 1997; 349: 1505-1510.

13. Armes JE, Egan AJ, Southey MC, Dite GS, McCredie MR, Giles GG, Hopper JL and Venter DJ. The histologic phenotypes of breast carcinoma occurring before age 40 years in women with and without BRCA1 or BRCA2 germline mutations: a population-based study. Cancer 1998; 83: 2335-2345.

14. Lakhani SR. The pathology of familial breast cancer: morphological aspects. Breast Cancer Res 1999; 1: 31-35.

15. Phillips KA. Immunophenotypic and pathologic differences between BRCA1 and BRCA2 hereditary breast cancers. J Clin Oncol 2000; 18: 107S-112S.

16. Foulkes WD, Stefansson IM, Chappuis PO, Begin LR, Goffin JR, Wong N, Trudel M and Akslen LA. Germline BRCAl mutations and a basal epithelial phenotype in breast cancer. J Natl Cancer Inst 2003; 95: 1482-1485.

17. Foulkes WD, Brunet JS, Stefansson IM, Straume O, Chappuis PO, Begin LR, Hamel N, Goffin JR, Wong N, Trudel M, Kapusta L, Porter $P$ and Akslen LA. The prognostic implication of the basal-like (cyclin E high/p27 low/p53+/glomeruloid-microvascular-proliferation+) phenotype of BRCA1-related breast cancer. Cancer Res 2004; 64: 830-835.

18. Foulkes WD, Metcalfe K, Sun P, Hanna WM, Lynch HT, Ghadirian P, Tung N, Olopade OI, Weber BL, McLennan J, Olivotto IA, Begin LR and Narod SA. Estrogen receptor status in BRCA I - and BRCA2-related breast cancer: the influence of age, grade, and histological type. Clin Cancer Res 2004; 10: 2029-2034.

19. Ridolfi RL, Rosen PP, Port A, Kinne D and Mike V. Medullary carcinoma of the breast: a clinicopathologic study with 10-year follow-up. Cancer 1977; 40: 1365-1385.

20. Rubens JR, Lewandrowski KB, Kopans DB, Koerner FC, Hall DA and McCarthy KA. Medullary carcinoma of the breast. Overdiagnosis of a prognostically favorable neoplasm. Arch Surg 1990; 125: 601-604.

21. Rapin V, Contesso G, Mouriesse H, Bertin F, Lacombe MJ, Piekarski JD, Travagli JP, Gadenne C and Friedman S. Medullary breast carcinoma. A reevaluation of 95 cases of breast cancer with inflammatory stroma. Cancer 1988; 61: 2503-2510.

22. Chappuis PO, Nethercot V and Foulkes WD. Clinico-pathological characteristics of BRCA1- and BRCA2 related breast cancer. Semin Surg Oncol 2000; 18: 287-295

23. Marcus JN, Watson P, Page DL, Narod SA, Lenoir GM, Tonin P, Linder-Stephenson L, Salerno G, Conway TA and Lynch HT. Hereditary breast cancer: pathobiology, prognosis, and BRCA1 and BRCA2 gene linkage. Cancer 1996; 77: 697-709.

24. Marcus JN, Watson P, Page DL, Narod SA, Tonin P, Lenoir GM, Serova $O$ and Lynch HT. BRCA2 hereditary breast cancer pathophenotype. Breast Cancer Res Treat 1997; 44: 275-277.

25. Agnarsson BA, Jonasson JG, Bjornsdottir IB, Barkardottir RB, Egilsson $\mathrm{V}$ and Sigurdsson $\mathrm{H}$. Inherited BRCA2 mutation associated with high grade breast cancer. Breast Cancer Res Treat 1998; 47: 121-127.

26. Garne JP, Aspegren K, Linell F, Rank F and Ranstam J. Primary prognostic factors in invasive breast cancer with special reference to ductal carcinoma and histologic malignancy grade. Cancer 1994; 73: 1438-1448.

27. Henson DE, Ries L, Freedman LS and Carriaga M. Relationship among outcome, stage of disease, and histologic grade for 22,616 cases of breast cancer. The basis for a prognostic index. Cancer 1991; 68: 2142-2149.

28. Palacios J, Honrado E, Osorio A, Cazorla A, Sarrio D, Barroso A, Rodriguez S, Cigudosa JC, Diez O, Alonso C, Lerma E, Sanchez L, Rivas C and Benitez J. Immunohistochemical characteristics defined by tissue microarray of hereditary breast cancer not attributable to BRCA1 or BRCA2 mutations: differences from breast carcinomas arising in BRCA1 and BRCA2 mutation carriers. Clin Cancer Res 2003; 9: 3606-3614.

29. Lynch BJ, Holden JA, Buys SS, Neuhausen SL and Gaffney DK. Pathobiologic characteristics of hereditary breast cancer. Hum Pathol 1998; 29: 1140-1144.

30. Clarke R, Liu MC, Bouker KB, Gu Z, Lee RY, Zhu Y, Skaar TC, Gomez B, O'Brien K, Wang Y and Hilakivi-Clarke LA. Antiestrogen resistance in breast cancer and the role of estrogen receptor signaling. Oncogene 2003; 22: 7316-7339.

31. Armes JE, Trute L, White D, Southey MC, Hammet F, Tesoriero A, Hutchins AM, Dite GS, McCredie MR, Giles GG, Hopper JL and Venter DJ. Distinct molecular pathogeneses of early-onset breast cancers in BRCA1 and BRCA2 mutation carriers: a population-based study. Cancer Res 1999; 59: 2011 1-2017.

32. Robson ME, Chappuis PO, Satagopan J, Wong N, Boyd J, Goffin JR, Hudis C, Roberge D, Norton L, Begin LR, Offit K and Foulkes WD. A combined analysis of outcome following breast cancer: differences in survival based on BRCA1/BRCA2 mutation status and administration of adjuvant treatment. Breast Cancer Res 2004; 6: R8-R17.

33. Osin P, Gusterson BA, Philp E, Waller J, Bartek J, Peto J and Crook T. Predicted anti-oestrogen resistance in BRCA-associated familial breast cancers. Eur J Cancer 1998; 34: 1683-1686.

34. Osin PP and Lakhani SR. The pathology of familial breast cancer: immunohistochemistry and molecular analysis. Breast Cancer Res 1999; 1: 36-40.

35. Hurlimann J, Larrinaga B and Vala DL. bcl-2 protein in invasive ductal breast carcinomas. Virchows Arch 1995; 426: 163-168.

36. Baccouche S, Daoud J, Frikha M, Mokdad-Gargouri R, Gargouri A and Jlidi R. Immunohistochemical status of p53, MDM2, bcl2, bax, and ER in invasive ductal breast carcinoma in Tunisian patients. Ann N Y Acad Sci 2003; 1010: 752-763.

37. Joensuu H, Pylkkanen L and Toikkanen S. Bcl-2 protein expression and long-term survival in breast cancer. Am J Pathol 1994; 145: 1191-1198.

38. Freneaux P, Stoppa-Lyonnet D, Mouret E, Kambouchner M, Nicolas A, Zafrani B, Vincent-Salomon A, Fourquet A, Magdelenat $\mathrm{H}$ and Sastre-Garau X. Low expression of bcl-2 in Brcal-associated breast cancers. Br J Cancer 2000; 83: 1318-1322.

39. Frierson HF, Jr., Gaffey MJ, Zukerberg LR, Arnold A and Williams ME. Immunohistochemical detection and gene amplification of cyclin D1 in mammary infiltrating ductal carcinoma. Mod Pathol 1996; 9: 725-730.

40. Gillett CE, Lee AH, Millis RR and Barnes DM. Cyclin D1 and associated proteins in mammary ductal carcinoma in situ and atypical ductal hyperplasia. J Pathol 1998; 184: 396-400.

41. Gillett C, Smith P, Gregory W, Richards M, Millis R, Peters G and Barnes D. Cyclin D1 and prognosis in human breast cancer. Int J Cancer 1996; 69: 92-99.

42. Loden M, Stighall M, Nielsen NH, Roos G, Emdin SO, Ostlund $\mathrm{H}$ and Landberg $\mathrm{G}$. The cyclin DI high and cyclin E high subgroups of breast cancer: separate pathways in tumorigenesis based on pattern of genetic aberrations and inactivation of the pRb node. Oncogene 2002; 21: 4680-4690.

43. Crook T, Brooks LA, Crossland S, Osin P, Barker KT, Waller J, Philp E, Smith PD, Yulug I, Peto J, Parker G, Allday MJ, Crompton $M R$ and Gusterson BA. p53 mutation with frequent novel condons but not a mutator phenotype in BRCA1 - and BRCA2associated breast tumours. Oncogene 1998; 17: 1681-1689.

44. Phillips KA, Nichol K, Ozcelik H, Knight J, Done SJ, Goodwin $\mathrm{PJ}$ and Andrulis IL. Frequency of p53 mutations in breast carcinomas from Ashkenazi Jewish carriers of BRCA1 mutations. J Natl Cancer Inst 1999; 91: 469-473. 
45. Goffin JR, Chappuis PO, Begin LR, Wong N, Brunet JS, Hamel $\mathrm{N}$, Paradis AJ, Boyd J and Foulkes WD. Impact of germline BRCA1 mutations and overexpression of p53 on prognosis and response to treatment following breast carcinoma: 10-year follow up data. Cancer 2003; 97: 527-536.

46. Greenblatt MS, Chappuis PO, Bond JP, Hamel N and Foulkes WD. TP53 mutations in breast cancer associated with BRCA1 or BRCA2 germ-line mutations: distinctive spectrum and structural distribution. Cancer Res 2001; 61: 4092-4097.

47. Ross JS and Fletcher JA. HER-2/neu (c-erb-B2) gene and protein in breast cancer. Am J Clin Pathol 1999; 1 12: S53-67.

48. Pauletti G, Godolphin W, Press MF and Slamon DJ. Detection and quantitation of HER-2/neu gene amplification in human breast cancer archival material using fluorescence in situ hybridization. Oncogene 1996; 13: 63-72.

49. Kallioniemi OP, Kallioniemi A, Kurisu W, Thor A, Chen LC, Smith HS, Waldman FM, Pinkel D and Gray JW. ERBB2 amplification in breast cancer analyzed by fluorescence in situ hybridization. Proc Natl Acad Sci U S A 1992; 89: 5321-5325.

50. Tsuda $H$, Akiyama F, Terasaki $H$, Hasegawa T, Kurosumi $M$, Shimadzu M, Yamamori S and Sakamoto G. Detection of HER2/neu (c-erb B-2) DNA amplification in primary breast carcinoma. Interobserver reproducibility and correlation with immunohistochemical HER-2 overexpression. Cancer 2001 ; 92: 2965-2974.

51. Johannsson OT, Idvall I, Anderson C, Borg A, Barkardottir RB, Egilsson $\mathrm{V}$ and Olsson $\mathrm{H}$. Tumour biological features of BRCA 1 induced breast and ovarian cancer. Eur J Cancer 1997; 33: 362-371.

52. Grushko TA, Blackwood MA, Schumm PL, Hagos FG, Adeyanju $M O$, Feldman MD, Sanders MO, Weber BL and Olopade OI. Molecular-cytogenetic analysis of HER-2/neu gene in BRCA1associated breast cancers. Cancer Res 2002; 62: 1481-1488.

53. Sorlie T, Tibshirani R, Parker J, Hastie T, Marron JS, Nobel A, Deng S, Johnsen H, Pesich R, Geisler S, Demeter J, Perou CM, Lonning PE, Brown PO, Borresen-Dale AL and Botstein D. Repeated observation of breast tumor subtypes in independent gene expression data sets. Proc Natl Acad Sci U S A 2003

54. Sorlie T, Perou CM, Tibshirani R, Aas T, Geisler S, Johnsen $H$, Hastie T, Eisen MB, van de Rijn M, Jeffrey SS, Thorsen T, Quist $H$, Matese JC, Brown PO, Botstein D, Eystein Lonning P and Borresen-Dale AL. Gene expression patterns of breast carcinomas distinguish tumor subclasses with clinical implications. Proc Natl Acad Sci USA 2001; 98: 10869-10874.

55. Simpson PT, Gale T, Reis-Filho JS, Jones C, Parry S, Steele D, Cossu A, Budroni M, Palmieri G and Lakhani SR. Distribution and significance of 14-3-3sigma, a novel myoepithelial marker, in normal, benign, and malignant breast tissue. J Pathol 2004; 202: 274-285.

56. Jones C, Mackay A, Grigoriadis A, Cossu A, Reis-Filho JS, Fulford L, Dexter T, Davies S, Bulmer K, Ford E, Parry S, Budroni M, Palmieri G, Neville AM, O'Hare MJ and Lakhani SR. Expression profiling of purified normal human luminal and myoepithelial breast cells: identification of novel prognostic markers for breast cancer. Cancer Res 2004; 64: 3037-3045.

57. Kovacs A and Walker RA. P-cadherin as a marker in the differential diagnosis of breast lesions. J Clin Pathol 2003; 56: 139-141.

58. Callagy G, Cattaneo E, Daigo Y, Happerfield L, Bobrow LG, Pharoah PD and Caldas C. Molecular classification of breast carcinomas using tissue microarrays. Diagn Mol Pathol 2003 12: 27-34.

59. van de Rijn M, Perou CM, Tibshirani R, Haas P, Kallioniemi $O$, Kononen J, Torhorst J, Sauter G, Zuber M, Kochli OR, Mross F, Dieterich H, Seitz R, Ross D, Botstein D and Brown P. Expression of cytokeratins 17 and 5 identifies a group of breast carcinomas with poor clinical outcome. Am J Pathol 2002; 161: 1991-1996.

60. Palacios J, Honrado E, Osorio A, Diez O, Rivas C and Benitez J. Re: Germline BRCA1 mutations and a basal epithelial phenotype in breast cancer. J Natl Cancer Inst 2004; 96: 712 714; author reply 714 .

61. van'† Veer LJ, Dai H, van de Vijver MJ, He YD, Hart AA, Mao M, Peterse HL, van der Kooy K, Marton MJ, Witteveen AT, Schreiber GJ, Kerkhoven RM, Roberts C, Linsley PS, Bernards R and Friend $\mathrm{SH}$. Gene expression profiling predicts clinical outcome of breast cancer. Nature 2002; 415: 530-536.

62. van der Groep P, Bouter A, van der Zanden R, Menko FH, Buerger $H$, Verheijen RH, van der Wall E and van Diest PJ. Re: Germline BRCA1 mutations and a basal epithelial phenotype in breast cancer. J Natl Cancer Inst 2004; 96: 712-713; author reply 714.

63. Lakhani SR, Gusterson BA, Jacquemier J, Sloane JP, Anderson TJ, van de Viiver MJ, Venter D, Freeman A, Antoniou A, McGuffog L, Smyth E, Steel CM, Haites N, Scott RJ, Goldgar D, Neuhausen S, Daly PA, Ormiston W, McManus R, Scherneck S, Ponder BA, Futreal PA, Peto J, Stoppa-Lyonnet D, Bignon YJ and Stratton MR. The pathology of familial breast cancer: histological features of cancers in families not attributable to mutations in BRCA1 or BRCA2. Clin Cancer Res 2000; 6: 782-789.

64. Hoogerbrugge N, Bult P, de Widt-Levert LM, Beex LV, Kiemeney LA, Ligtenberg MJ, Massuger LF, Boetes C, Manders P and Brunner HG. High prevalence of premalignant lesions in prophylactically removed breasts from women at hereditary risk for breast cancer. J Clin Oncol 2003; 21: 41-45.

65. Kauff ND, Brogi E, Scheuer L, Pathak DR, Borgen PI, Hudis CA, Offit $\mathrm{K}$ and Robson ME. Epithelial lesions in prophylactic mastectomy specimens from women with BRCA mutations. Cancer 2003; 97: 1601-1608.

66. Adem C, Reynolds C, Soderberg CL, Slezak JM, McDonnell SK, Sebo TJ, Schaid DJ, Myers JL, Sellers TA, Hartmann LC and Jenkins RB. Pathologic characteristics of breast parenchyma in patients with hereditary breast carcinoma, including BRCA1 and BRCA2 mutation carriers. Cancer 2003; 97: 1-11.

67. King MC, Wieand S, Hale K, Lee M, Walsh T, Owens K, Tait J, Ford L, Dunn BK, Costantino J, Wickerham L, Wolmark N and Fisher B. Tamoxifen and breast cancer incidence among women with inherited mutations in BRCA1 and BRCA2: National Surgical Adjuvant Breast and Bowel Project (NSABP-P1) Breast Cancer Prevention Trial. Jama 2001; 286: 2251-2256.

68. Clarke RB, Howell A, Potten CS and Anderson E. Dissociation between steroid receptor expression and cell proliferation in the human breast. Cancer Res 1997; 57: 4987-4991.

69. Rebbeck TR, Levin AM, Eisen A, Snyder C, Watson P, CannonAlbright L, Isaacs C, Olopade O, Garber JE, Godwin AK, Daly MB, Narod SA, Neuhausen SL, Lynch HT and Weber BL. Breast cancer risk after bilateral prophylactic oophorectomy in BRCA 1 mutation carriers. J Natl Cancer Inst 1999; 91: 1475-1479.

70. Narod SA, Brunet JS, Ghadirian P, Robson M, Heimdal K, Neuhausen SL, Stoppa-Lyonnet D, Lerman C, Pasini B, de los Rios $\mathrm{P}$, Weber $\mathrm{B}$ and Lynch $\mathrm{H}$. Tamoxifen and risk of contralateral breast cancer in BRCA1 and BRCA2 mutation carriers: a case-control study. Hereditary Breast Cancer Clinical Study Group. Lancet 2000; 356: 1876-1881. 